\title{
Museum Techniques for Educational Tourism Visitors
}

\author{
Mayada Belal, Nievin Nizar, Ussama Abd El Wareth \\ Fatma Ahemd Soliman
}

Heritage and museum studies department, Helwan University 2021

\begin{abstract}
:
Museums are mainly culture institution and playing very effective role in culture tourism as informal tool for learning and enjoyment.

The number of Egyptian museum visitors are $80 \%$ travelers for culture tourism to explore, learn, and enjoy art and heritage of the different cultures such as the ancient Egyptian history, GrecoRoman, Coptic and Islamic cultures where the researchers can find so many values for tangible and intangible values.

Moreover, the Egyptian museums are full of knowledge, which are target for so many researchers from all over the world.

The idea of the research came after several international educational institution such as Kazakhstan and Netherlands asked to guide their students for culture tours as they teach them Islamic and Arabic language but miss a about practice and culture of the country.

Therefore, the museum can be very powerful engine of economic development through educational tourism as full package of services.
\end{abstract}

\section{Key words:}

Educational Tourism/ Self-Sufficient Museums/ Tourism/ Sustainability/ Museum's Visitors.

\section{Introduction}

Traveling is a human habit since the Dawn of history for many motivation reasons whatever to explore, enjoy, learn, exchange knowledge, learn languages and improve personal social skills, which means for learning, social, and entertainment purposes.

The oldest example of travelling to learn when the ancient Egyptian temple was the source of knowledge to learn how to read \& write.

Then trough Greco Roman era the Library of Alexandria and the museum was the source of science and knowledge where students came from all over the ancient world to study then transfer their knowledge to Europe. 


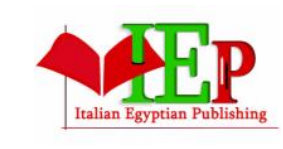

ISSN: $2735-5462$

\section{INTERNATIONAL JOURNAL OF \\ ECO-CULTURAL TOURISM, HOSPITALITY PLANNING \\ AND DEVELOPMENT}

VOLUME 4, ISSUE 1, 2021, 49-71.

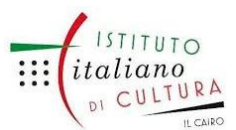

www.egyptfuture.org/ojs/

Ptolemy I established the library (between 323 and 285 BC), the ancient library of Alexandria was part of an institution of higher learning known as the Alexandrian Museum. The library was intended as a resource for the scholars who did research at the Museum.

Scholars working at the Alexandrian Museum used the ancient library to create the categorization of Ancient Egypt's history into 30 dynasties, which is still used today when we study ancient history. The Bibliotheca Alexandrina houses the world's largest digital collection of historical manuscripts as well as the largest repository of French books on the African continent.

Then through medieval era, Baghdad and Cairo were the target for learning which courage the kings and rich people to establish hostels for them to stay inside the religious buildings and companied with rooms, library.

One of the best examples for such complex is the sultan Hassan Madrasa 1356 A.D where are 240 rooms for students who can stay at the place of learning.

Egypt modern era has one of the oldest universities that is located at Cairo University, which is considered the first university in the ARAB area, which became the second homeland for thousands of students form all Arab land.

Since $18^{\text {th }}$ and $19^{\text {th }}$ century Egyptian history start to attract so many researchers which created the science of Egyptology, which raised up in Europe and start to courage a lot of travelers to buy ancient Egyptian objects and make their own display even more try to study for better understanding till now thousands of students, researchers, archaeologists, historians, artists, heritage experts try to learn more about Egyptology wherever at the international museums or travelling to Egypt for practical practice.

According to world Travel \& Tourism, association (WTTA) magazine, Museum is considered one of the main attractions for culture tourism, which is part of the main sources to raise resources and hard currency with about $38 \%$ of the countries around the world.

The number of students enrolled in institutions of higher education outside their countries of origin has risen greatly since 1999 and part of those affiliated institutions are the museums, nowadays paid internship in top museums reached up to 16,500 English pound, as direct revenue from educational tourism and activities.

Travel and tourism sector plays a significant role in the economic state of a country

Learning foreign languages is remarkable market of this type of educational tourism especially in the countries use a language widely used internationally, which is one of the main reasons for travelling for educational tourism. 


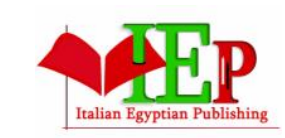

ISSN: $2735-5462$
INTERNATIONAL JOURNAL OF

ECO-CULTURAL TOURISM, HOSPITALITY PLANNING

AND DEVELOPMENT

VOLUME 4, ISSUE 1, 2021, 49-71.

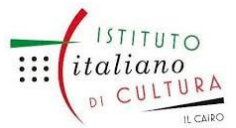

www.egyptfuture.org/ojs/

While the current revenues of language in Europe schools are only 15 million euro, it is estimated that there is a potential market of 375 million people who want to travel to learn a language, especially if this experience is combined with other activities that are based on the local culture (GLOBAL, 2021).

\section{Museum as a Hub for Educational tourism}

The Main and clear function of museums that the museum is an informal Education destination with so many potential values can be useful to create new types of tourism.

IN December 2018, ICOM and OECD joined forces to launch Culture and Local

Development: Maximizing the Impact of museums (ICOM, p. 2021)

The educational tourism sector is generally an overlooked sub-sector of the tourism market. This is largely due to a lack of understanding about the concept of educational tourism, its value to the visitor economy and associated output. This paper presents a definition and illustrates how most students travelling to destinations tend to be motivated by a desire to learn, moreover to explore, entertainment, social reasons and enjoyment. (https://www.cabdirect.org/cabdirect/abstract/20103311195\#, 26/04/2021).

So many countries could recognize the benefits can be generated form Education and especially as a culture and heritage center especially museums where enough tools, objects, space and the most important no doubt is the visitor.

\section{Methodology of the research:}

Literature review, field study in Egypt, interviews with museum experts and tourism professionals and researchers, competitive and qualitative studies.

\section{Objectives:}

- Make the museums as hub of educational tourism.

- Benefit and improve new type of tourism.

- Reorganize activities related to culture tourism education experience with all suppliers of services.

- $\quad$ Raise resources of the museum to be self-sufficient.

- Make the Egyptian museums the main center for Egyptology and Archaeology.

- Raise the value of Socio- economic role of museum in sustainability.

- Use Educational tourism as one of the soft power tools in Egypt.

Target groups are

1- Culture tourism stakeholders

2- Researchers of Art, History and Archaeology

3- Language learners 
4- Families of the researchers.

5- Foreign students.

anciationifatstdenending on which of the two is the main aim of the travelers educational

\section{Types of Educational tourism techniques}

General learning or purposeful learning, which both happen while traveling. The first type takes place when individuals take part in guided tours and programs that they organize on their own while traveling. The second type is when travelers attend educational or training courses, tours even more through virtual more over new type of educational programs created upon the pandemic of corona virus which is the on line educational programs accompanied with traveling experience through virtual channels so online can be the link between on line visitors to start to think about physical visit and can be some cyber paid programs with several levels.

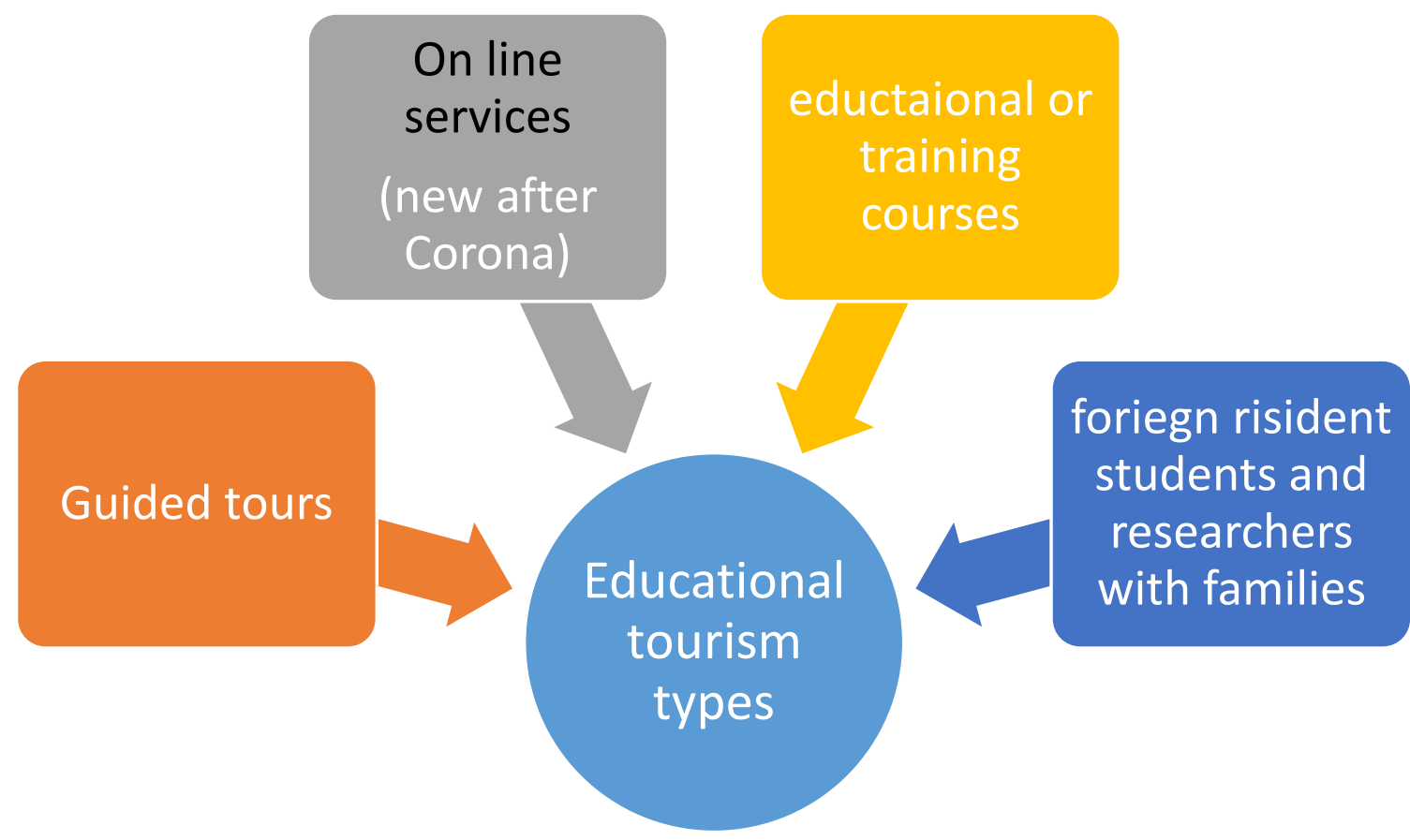

Chart 1.Types of tourism Education

\section{Advantage of educational tourism}

1- Tourism sector is one of the main Job opportunity creation around the world.

2- Supply of goods and services via local companies such as food and furniture.

3- Sales of goods and services as retailers in tourist destination sell their products to tourists.

4- Tourism enterprises foundation as this creates job opportunities. 


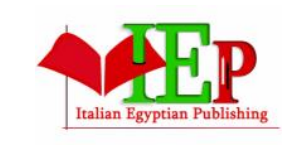

ISSN: $2735-5462$

\section{INTERNATIONAL JOURNAL OF \\ ECO-CULTURAL TOURISM, HOSPITALITY PLANNING \\ AND DEVELOPMENT}

VOLUME 4, ISSUE 1, 2021, 49-71.

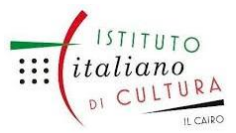

www.egyptfuture.org/ojs/

5- It's one of the sources to generate tax to the countries from tourism companies and suppliers.

6- Investment in infrastructure to meet the needs of the tourism sector and its expansion.

7- Tie the world together by understanding and exchanging knowledge.

As a result, museum as part of tourism Education can be divided into two main aspects which are

. Indirect impact: these are the effects of the activities done by the sector of tourism. These are directly related to three elements: capital investment in tourism, government spending on tourism with its official authority , and supply chain effects such as tour leaders, drivers, guides, hotel staff.

3. services impacts: These include food \& beverages, recreation, clothing, housing, and household goods which full needs of life for travelers and visitors.

\section{Tourism impact on the Egyptian economy}

So clear to figure out the income of tourists who visited Egypt in 2009 (2009 and 2010 are the 2 peak seasons before the demonstration 2010). That is meant that Egypt has the opportunity to attract a huge number of visitors and revenue from tourism $\left({ }^{1}\right)$ especially culture tourism. Museums are considered as part of the culture heritage tourism harmony as tourism is one of the main sources of income and share with the national income with about $38 \%$ in whole over the world as industry of petroleum and chemicals are the first productions then third is tourism which museums are part of it, Tourism is an important element of the economy of Egypt according to the analytic of tourism 2019 by the ministry of tourism and antiquities.

The income of tourism in 2018, total revenue from tourism in Egypt reached EGP 174.1 Billion, a $124 \%$ increase on the previous year, representing $15 \%$ of the country's GDP. The tourism sector is one of the largest employers in Egypt, providing 3.1 million jobs or 9.5\% of the total workforce.

In 2018, Egypt recorded 9.8 million international arrivals, an increase of $48 \%$ compared to the previous year. The majority of international tourist arrivals were from European countries (59\%), with most arrivals from Germany, Ukraine and the United Kingdom, the Middle East

${ }^{1}$ (Global Heritage Fund Estimates and Published Data) 


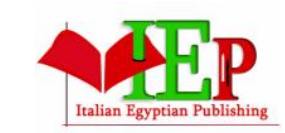

ISSN: $2735-5462$

\section{INTERNATIONAL JOURNAL OF \\ ECO-CULTURAL TOURISM, HOSPITALITY PLANNING AND DEVELOPMENT}

VOLUME 4, ISSUE 1, 2021, 49-71.

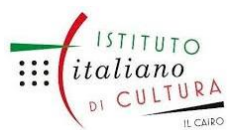

www.egyptfuture.org/ojs/

(22\%), with most arrivals from Saudi Arabia and Jordan and African countries (7\%), with

Sudan being the key market.

The Egyptian museum at Tahrir is one of the main attractions which is representing $95 \%$ of Cairo foreign visitors as part of Cairo Itinerary where visitors include pyramids with the museum tour when the visitor has one day at Cairo and other offer when he got 2 days tours at the Cairo so second day the museum is part of the as city tour.

\begin{tabular}{|l|l|l|l|} 
City & \multicolumn{1}{c}{ Site } & \multicolumn{1}{c}{ Tourist } & \multicolumn{1}{c|}{$\begin{array}{c}\text { Egyptian\& } \\
\text { Arabs }\end{array}$} \\
\hline Cairo & Ancient Egyptian museum & 381639 & 269182 \\
\hline Cairo & Coptic museum & 102792 & 128249 \\
\hline Cairo & Islamic museum & 1212 & 450 \\
\hline & Other tourist sites & 205219 & 657344 \\
\hline $\begin{array}{l}\text { Total } \\
\text { Cairo }\end{array}$ & & 690862 & 1055225 \\
\hline
\end{tabular}

Table 1. Shows number of visitors to main sites \& museums around Cairo 2015 (p. interior affiars 2016) 
INTERNATIONAL JOURNAL OF

ECO-CULTURAL TOURISM, HOSPITALITY PLANNING

AND DEVELOPMENT

\section{international touirst}

2018:2019 - 2017:2018 $\quad 2009: 2010$

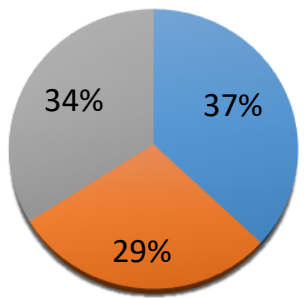

Chart shows the international tourist arrival between, 2009:2019

that Egyptian tourism which could raise up $\mathbf{2 9 \%}$ 2018:2019 which could get $\mathbf{1 2 . 6}$ million \$ dollars comparing with 2017:2018 which reach 9.8 million \$ dollars, while at the More over the main principals to gain the target of the museum to serve and make the museum running, museum must concern about several principals as follow Museum must be designed to be as universal design to welcome and serve all type of audience ( National or international), individual or groups with best high quality_and satisfaction.

2019 arrivals data for Egypt is only available for the first two months of 2019 and shows double -digit growth, these positive development is the result of the care of improving tourism sector through technology, sustainable tourism strategies and empowering women as the minister was DR Rania El Mashat who has economic studies back ground, which gives good impact on the progress of the importance of woman's power.

\begin{tabular}{|c|c|c|c|c|c|}
\hline Year & 2015 & 2016 & 2017 & 2018 & 2019 \\
\hline $\begin{array}{l}\text { Income by } \\
\text { milliard }\end{array}$ & 6.07 & 2.6 & 7.7 & 11.6 & 14.000 \\
\hline
\end{tabular}

Table shows income of tourism by milliard (ministry of tourism and Antiquities) 


\section{Impact of museums in Strategic plan of sustainability}

Tourism is considered one of the main income sources for Egypt no doubt museums are part of tourism tool as one of the attractions for visitor's especially ancient Egyptian museum.

According to the secured political situation, the number of museum's visitors could raise and have reached 9,643 (millions) 2016 distributed as follow:

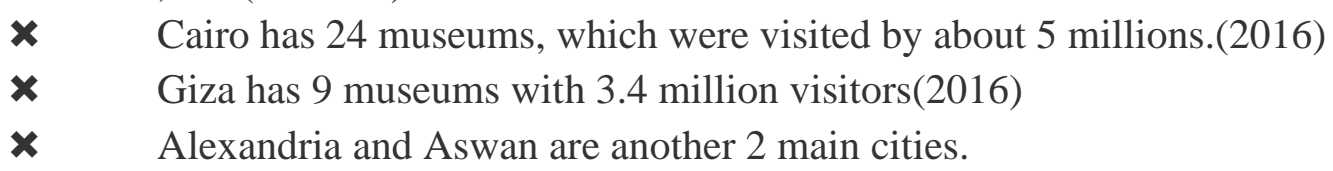

\begin{tabular}{|l|c|c|c|}
\hline \multicolumn{1}{|c|}{ The city } & Cairo & 9 & $\begin{array}{c}\text { Alexandria \& Aswan + 2 } \\
\text { main cities }\end{array}$ \\
\hline Number of museums & 24 & 3.4 & .6 \\
\hline $\begin{array}{l}\text { Visitors of the museum } \\
\text { (MILLIONS) }\end{array}$ & 5 millions & & \\
\hline
\end{tabular}

Table shows the number to museums and their visitors 2016

The higher percentage of museum's visitors go to the Egyptian museum at Cairo $\left({ }^{2}\right)$, also National museum of Egyptian civilization, Islamic museum, Coptic museum and Grand Egyptian museum (Gem) is coming soon to be the main museum at the city instead of the ancient Egyptian museum which is expected to have 15.000 visitors a day which also includes children museum, conservation center and huge open area space, which raise opportunities for the benefits can generate from the museums.

\section{Impact of visitors of museums at Egyptian income}

- Visitor exports generated EGP59.6 billion in 2014 (17.4\% of total exports for that year)

- This is forecast to grow 4.2\% per annum from 2015-2025

- Gross Domestic Product (GPD) total contribution of tourism in 2014 was EGP225.0 billion (12.8\% 0f GDP for that year), while within 2019 Egypt could get +20 up through June comparing with same period the year before (world tourism barometer, p. 2019).

- Estimated 1 in 7 Egyptians rely on tourism for a living.

\footnotetext{
${ }^{2}$ ) It is noticed that Domestic visitors always less than international visitors and also the Egyptian number includes Arab visitors as the buy same fee tickets.
} 


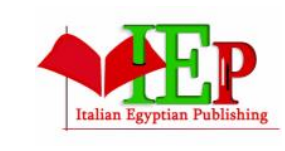

ISSN: 2735-5462
INTERNATIONAL JOURNAL OF

ECO-CULTURAL TOURISM, HOSPITALITY PLANNING

AND DEVELOPMENT

VOLUME 4, ISSUE 1, 2021, 49-71.

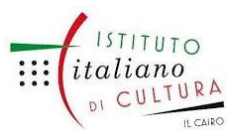

www.egyptfuture.org/ojs/

- Travel and tourism generated 1,322,500 jobs directly in 2014 (5.2\% of total employment). Employments include hotels, travel agents, airlines and other passenger transportation services, activities of the restaurant and leisure industries directly supported by tourists $\left(^{3}\right)$.

While museum is a culture and learning experience through objects, interpretation with new techniques to create new ideas to attract more visitors with different needs and keep repeat the experience for more knowledge and enjoyment while spending time and money to get the best of the economic experience.

\section{Museum without visitor is lifeless}

\section{Type of Educational Tourism programs Organized by museums}

Museums must study the demography of its visitor such as age, gender, education level, nationalities, seasons, and physical or mental ability of participants and be a hub for culture tourism and partner with business in the urban and region.

A- School trips: they are short or medium stays since the students are of low age. They are usually programmed by teachers or their parents through private agencies or through scholarships that the Ministries of Education provide. They can be trips to develop another language or cultural knowledge through several activities around the year or according and be part of their curriculum, or summer camps to improve their knowledge trough travelling and can be through organizing camps and travel for foreign students with local native students.

B- Experiences of university studies: there are various programs that facilitate the experience of students in a country within the common framework as example come to visit store rooms of the museums or have practical conservation training for art or antiquities at the Egyptian labs.

\section{C- Experience of experts training studies:}

There are many programs especially in the field of conservation, restoration, exhibitions and display techniques or go to share the experience of field work at the Archaeology sites.

More over some other type of Educational tourism activities can be included which are as follow:

D- Conferences and academic researchers: this another type of educational tourism gate such as the annual conference of the archaeologists and king's Tut annual conference organized by the Grand Egyptian museum which has several experts attendees from all over the world.

E- Adults Travelers who travel for culture tourism education: This type of visitors need to learn about different cultures, which is the main motivations to visit the museum.

\footnotetext{
$\left.{ }^{3}\right)$ Invalid source specified.
} 


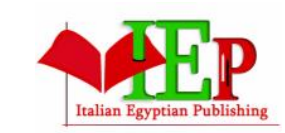

ISSN: $2735-5462$
INTERNATIONAL JOURNAL OF

ECO-CULTURAL TOURISM, HOSPITALITY PLANNING AND DEVELOPMENT

VOLUME 4, ISSUE 1, 2021, 49-71.

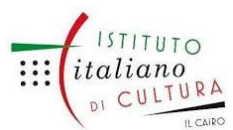

www.egyptfuture.org/ojs/

Nowadays with new circumstances of Covid-19 people under control of travelling start to deal more with virtual activities so it is a chance to create and use this tool as another benefit for virtual visitors.

F- On line activities such as meetings, webinars, conferences, lectures and virtual tours so the ministry of tourism \&Antiquities

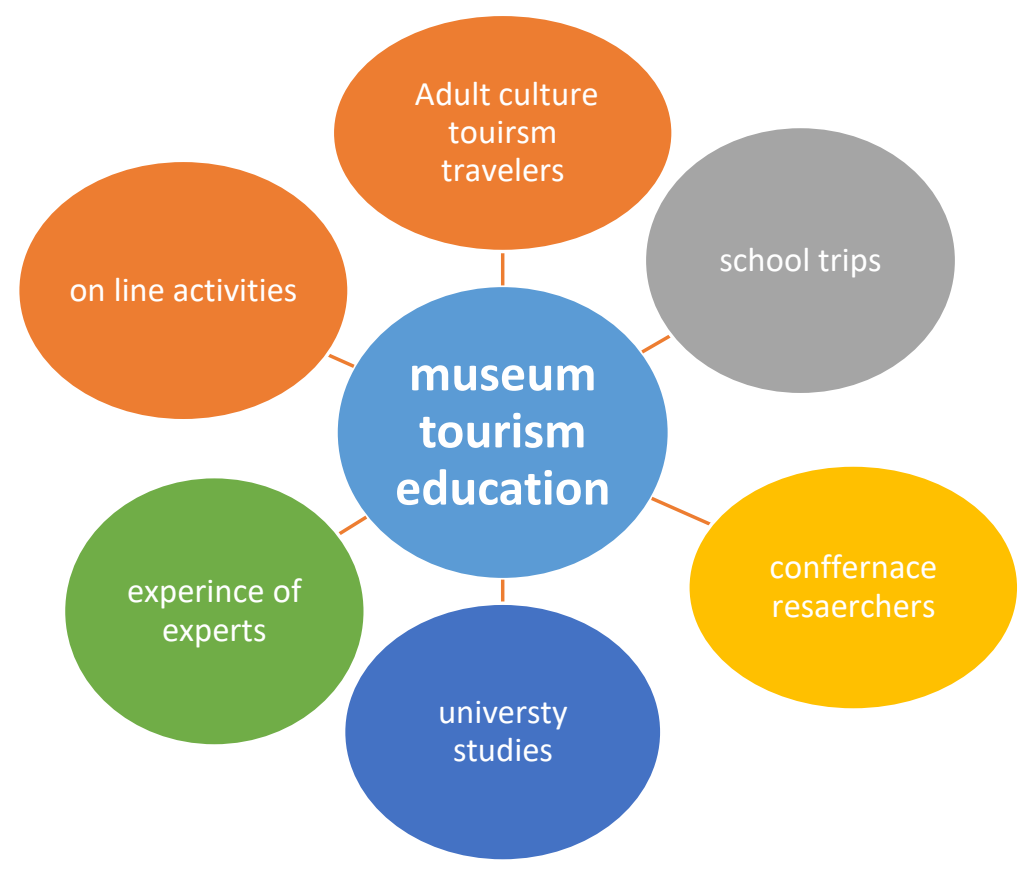

Graph NO.1 museum educational tourism programs

This type of new activities start to be new idea of the museum to use within the time of Covid19 when the quarantine and most of the museums locked down, so many virtual activities start 


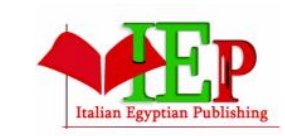

ISSN: $2735-5462$
INTERNATIONAL JOURNAL OF

ECO-CULTURAL TOURISM, HOSPITALITY PLANNING

AND DEVELOPMENT
$:: \begin{gathered}\text { istituto } \\ \text { italiano } \\ \text { oI CULTURA }\end{gathered}$

www.egyptfuture.org/ojs/

to replace the Physical visit such as virtual tours by the ministry of Antiquities and tourism in Egypt for few minutes virtual tours from different museums but for free while an international associations called museum next start to organize a summit of how to raise the revenue of museum 20: 23 of June 2021 and sponsored by ART-FUND, Association for cultural enterprises, code mantra, Vastri and trusteed by leading museums TATE, THE MET, RUKS MUSEUM, Qatar museum, Natural history museum, Smithsonian, MoMA AND V\&A.

The event features more than thirty international speakers over three days, with actionable presentations offering strategies to boost your museum's digital revenue.

And after the conference you'll have on-demand access to the talks until the end of 2021.

An institutional ticket gives everyone in one organization access to the event for $£ 240$. This includes the option of watching the event live as well as on-demand access to the films of the event for your entire staff.

An individual ticket gives one-person access to the event for $£ 120$. This gives you the option to watch the event live as well as on-demand access to the films of the event after it has taken place (https://www.museumnext.com/events/digital-income-summit/, p. MAY 2021 )

\section{Direct Programs that museum handle}

Training may be required for:

\section{(Areas of knowledge in the museum)}

- Care of collections and Conservation

$\circ$ packing and handling procedures

- Documentation procedures

- Museum operations and administration

- Staff and site management

- Marketing, Public Relations and Evaluation

- Interpretation and education programs

- Exhibition design

$\circ$ financial planning and fundraising

○ Digitization of collections

- Museum security

- Cultural planning. 
○ Achieving skills

- Libraries operation systems.

- Policies and strategic plans of culture institutions.

\section{Resources:}

Workshops

Seminars

In-house training sessions

In-house library of books and periodicals on museology

Conferences

Internships

Visits and study tours

Meetings of regional museums groups

Audio-visual education kits

University/college courses

Museums studies programs

Professional exchanges

Active participation in professional associations.

Use of information technology and professional literature to keep feeding of professional developments and policies in direct and related areas.

Additionally Tourism services \& activities such as accommodation, traveling tickets, food\& beverage, transportation and domestic sights visits for the foreign resident and their visitors.

(The Ontario Ministry of Culture and Communications, Ontario Museum Notes: Practical Information on Operating a Community Museum, Number 10 Developing a Staff Training Policy)

\section{Indirect Role of Museums in Educational Tourism}

- Learning Arabic language, which is start to be one of the main Languages for western to learn and have good opportunity at Gulf area or oil companies and Hospitals.

- Speak Arabic which course target second and third generation of Arab immigrants, which is became a mission from the ministry of immigration in Egypt.

- Learn religious subjects at El Azhar or Christian Coptic Art and history.

- Learn the ethnography about Arab culture for political science. 
INTERNATIONAL JOURNAL OF

ECO-CULTURAL TOURISM, HOSPITALITY PLANNING

AND DEVELOPMENT

- Any foreign researcher should be part of his curriculum to use the museum as mediate for services and facilities to stay with protocol with the other ministries

\section{Examples of international training programs mange by museums}

\section{1- Program OF ITP with the British museum}

Every summer, the British Museum runs a training program for museum and heritage professionals from around the world, with up to 26 participants spending six weeks in the UK.

(https://www.britishmuseum.org/our-work/international/international-trainingprogramme , 2021 )

\section{2- Smithsonian Unit Internship:}

These are internship opportunities available at each of the Smithsonian's various museums, research centers, and other units, The Smithsonian museum offers 54 different scholarship programs (https://www.smithsonianofi.com/internship-opportunities/, 2021).

\section{3- Internship in Florence, Italy}

Florence has been called Italy's capital of culture; Thousands of years of history, artwork, literature, policies and industry have given the city an unpatrolled cultural heritage. Taking an internship in Florence will give you opportunities to grow in a city of living history, with the breadth of fields in this amazing city.

(https://www.gooverseas.com/internships-abroad/italy/florence , 2021 )

4-Training at Vatican: Training at Vatican, which is a conservation training. https://www.museivaticani.va/content/museivaticani/en/musei-delpapa/stage.html

5-The Bilbao Fine Arts Museum (Basque Country, Spain) The Bilbao Fine Arts Museum is one of the richest Spanish museums outside Madrid. Students of universities up to the age of 35 who are interested in preserving and restoring art objects are invited Successful

\section{applicants are paid a grant of 15000}

Euros. (https://theculturetrip.com/europe/spain/articles/the-best-galleries-and-museums-in-b, p. 2021) 


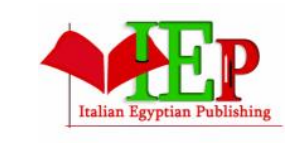

ISSN: $2735-5462$

\section{INTERNATIONAL JOURNAL OF \\ ECO-CULTURAL TOURISM, HOSPITALITY PLANNING \\ AND DEVELOPMENT}

VOLUME 4, ISSUE 1, 2021, 49-71.

www.egyptfuture.org/ojs/

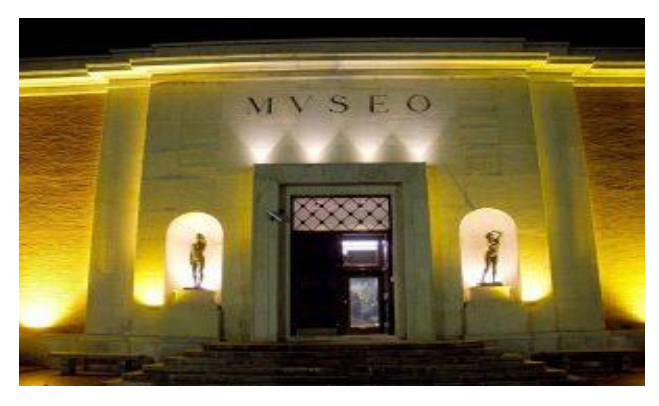

4- The National Palace Museum, located in Taipei and Taibao, Taiwan

The main goal of this internship program is to provide graduate and undergraduate students an internship opportunity involving museum conservation practice. Corresponding to space limitations, the internship program, positions in Chinese painting conservation section are limited to 3 interns each year, one at a time, and 2 interns in object conservation section and books and archives conservation section each year. Internship is suitable for art-experts. The museum pays only for visa and medical insurance, but it provides accommodation.

5- National Gallery of Art, Washington: The National Gallery of Art, one of the world's preeminent museums, preserves, collects, exhibits, and fosters the understanding of works of art at the highest possible museum and scholarly style.

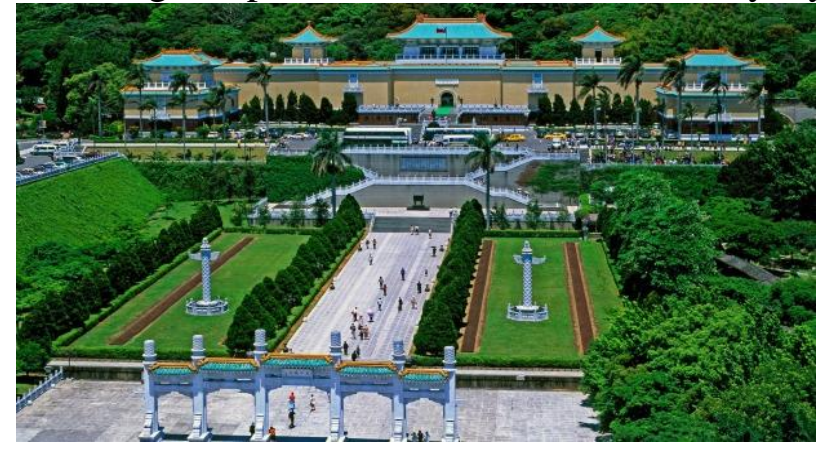




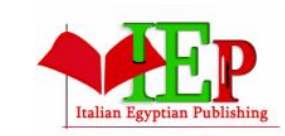

ISSN: 2735-5462
INTERNATIONAL JOURNAL OF

ECO-CULTURAL TOURISM, HOSPITALITY PLANNING

AND DEVELOPMENT

VOLUME 4, ISSUE 1, 2021, 49-71.

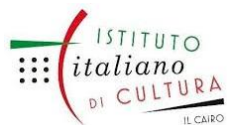

www.egyptfuture.org/ojs/

\section{9- New Museum of Contemporary Art}

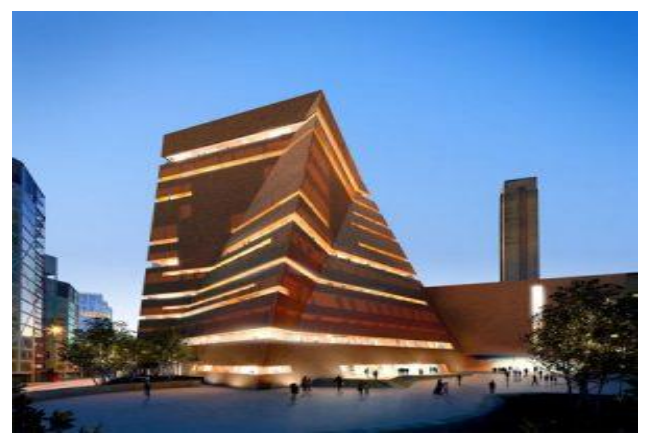

Founded in 1977 by Marcia Tucker, is a museum in New York City at 235 Bowery, on Manhattan's Lower East Side. It is among the few contemporary art museums worldwide exclusively devoted to presenting contemporary art from around the world.

The museum is in the list of three best museums of contemporary art in the world and offers an incredible variety of paid internships. In addition, the museum helps with the registration of an American visa.

\section{0- Internship Program in Germany}

Cultural Vistas' Internship Program in Germany provides excellent opportunities for students to gain valuable international work skills, improve German language abilities, and experience German life and culture firsthand (https://culturalvistas.org/programs/internshipsabroad/gip/internship-program-germany/, p. 2021).

\section{1- Japan International Cooperation Agency}

To achieve JICA's mission of achieving "human security and quality growth," JICA issues bonds in the capital market to fund projects in developing countries. JICA bonds are for those investors who look for reliable investment opportunities with socially contributive nature.

(https://www.jica.go.jp/english/ir/financial/index.html , 2020)

\section{Arab Museums Educational Programs}

Educational tourism is becoming a popular destination in major key cities around the world and Dubai, United Arab Emirates, is one of the leading destinations in that aspect. Dubai's reputation in the tourism industry is remarkable as it offers better infrastructure, quality of life, and most of all a very safe place for education, tourism, and more. Educational tourism in Dubai plays significant role in knowledge management across society

There are so many educational museum programs around the world While Arab countries start recently to have limited examples such as:

1- Sharjah museum internship 


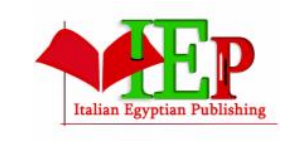

ISSN: 2735-5462
INTERNATIONAL JOURNAL OF

ECO-CULTURAL TOURISM, HOSPITALITY PLANNING

AND DEVELOPMENT

VOLUME 4, ISSUE 1, 2021, 49-71.

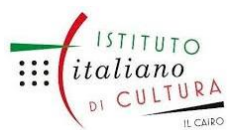

www.egyptfuture.org/ojs/

2- Qatar museum internship

3- Bahrain Museum

4- Arab educational institute with a wall museum at Jerusalem into Bethlehem. In 2009, four women groups came together for weekly meetings and various social activities. Among those activities were cultural events like the formation of a large human Bethlehem star; the singing and playing from roofs and balconies along the streets; a concert from down under a military watchtower; meditative and inter-religious sessions, and the establishment of a women's choir performing next to the Wall which forbidden to go across.

It became an annual Festival in the area. Other Wall-torn cities, provided models of inspiration, like Berlin and Belfast walls.

\section{Educational Tourism for Museum's Visitors}

Museums of $21^{\text {st }}$ century can be a center for educational tourism specially which effects culture, artistic and social, and economic performance of the museum and generated by the museum, It is very important to understand the society needs who needs more of educational tourism and more important to respond to the growth and transfer of it to be useful for the new generations and their needs and difference between ages to improve the guest experience as much as possible.

For those who are looking for an educational tourism experience, the most important thing a trip can offer is to learn new languages, complement their training, broaden their work horizons and live with different cultures.

The significant volume and value of Egyptian education tourism is presented, with examples on the international university student market, as well as its impact on visitor economies. The case for more active and effective collaborative marketing is shown through examples of current good practice at the museums managements, which can be adapted at the Egyptian museums with its powerful tools.

Egyptian history museums can be great source of income by using its tools, techniques and make the museum self-sufficient.

(https://www.cabdirect.org/cabdirect/abstract/20103311195\#, 26/04/2021)

\section{Techniques of Handling Educational Tourism through the Museum}

There are so many programs Egyptian museums can adapt for scholars according to the uniqueness of the collections especially at the Grand Egyptian museum, which is the largest museum for ancient Egyptian history, art, and heritage. 


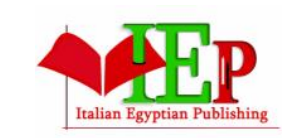

ISSN: $2735-5462$

\section{INTERNATIONAL JOURNAL OF \\ ECO-CULTURAL TOURISM, HOSPITALITY PLANNING \\ AND DEVELOPMENT}

VOLUME 4, ISSUE 1, 2021, 49-71.

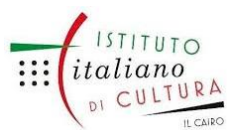

www.egyptfuture.org/ojs/

Moreover is supported by the international willing to support as well as the National museum of Egyptian civilization which supported by the UNESCO.

- Teaching the Ancient Egyptian music.

- Teach ancient Egyptian languages Hieroglyphic, demotic and Coptic even Arabic

- Special art, fashions, handicrafts and designs with Egyptian techniques and motives.

- Create some new curving festivals as the symposium of Aswan for sculptures.

- Archelogy and field excavation courses.

- Conservation and preventive preservation courses.

- Exhibition and design programs.

- Conservation and preventive preservation courses.

- Exhibition and design programs.

- Literature of Ancient Egypt, Coptic or Islamic periods.

- Ethics of the curator ship

- Ethnography of ethnic groups.

- Family programs especially with school age to learn, stay, enjoy with families In addition, so many other programs about plants, animals.

More over the museums can offer it for hosting important events such as famous brands, international sports events that push so many activities to involve in such events.

The courses can be for single topic or as packages according to the requests of visitors.

\section{Partners of educational tourism in Egypt}

\section{Partners of the educational tourism in Egypt can be working through 2 main channels} which are

1- First Domestic entities

2- Second international entities

First Domestic it works through two main channels which are Official and authority of stakeholders to give legal work and power to be under services and legal control, to open the gate which are the ministry of tourism, Egyptian Travel Agents Association, ministry of youth, ministry of high studies, ministry of social work, ministry of foreign affairs, ministry of culture, additionally NGO'S and educational institutions such as:

- International schools, universities, embassies and companies.

- $\quad$ Some private sectors such as KIDZINIA \& NGO'S.

- The governmental associations.

\section{Second the international entities}

The museum can be the center for educational tourism for International visitors especially researches and so many organizations could start some activities and funded for their programs.

1- Egypt exploration society which supported by the British council. 


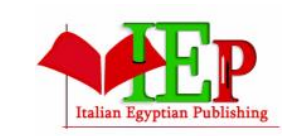

ISSN: 2735-5462

\section{INTERNATIONAL JOURNAL OF \\ ECO-CULTURAL TOURISM, HOSPITALITY PLANNING \\ AND DEVELOPMENT}

VOLUME 4, ISSUE 1, 2021, 49-71.

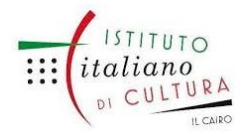

www.egyptfuture.org/ojs/

2- AERA (American research center association) in 2005, when it was launched first AERA-ARCE Archaeological Field School to train inspectors \& curators from the Egyptian Ministry of Antiquities in advanced excavation techniques and archaeological material culture analysis and it's supported by the USAID. (http://www.aeraweb.org/field-school-program/, p. 2021)

3- The British museum, which adapted the International annual training course, controlled by the British museum dedicated for the developing countries and supported by the museum resources.

4- Smithsonian art museum support scholars of art for courses and visit to the museum to improve their skills.

5- Italian institute of Archaeology, This program is an exciting and unique opportunity for a firsthand look at archaeological fieldwork and a new approach in understanding ancient civilizations. It gives the opportunity to learn and work in a real excavation environment, it is on summer

In addition, another program by Archaeological conservation institute which started educational program since 2011.

(https://ldminstitute.com/academics/programs-and-degrees/study-abroad-programs/summerprograms/archaeology-field-school/, p. 2021) \& (https://www.archaeologicalconservation.org, )

6- Japanese international cooperation association which based at Minpaku ethnographic museum where the program supports scholars from developing countries and supported by the Japanese government and facilitate their visit and stay in different cities of Japan as part of attracting visitors to understand Japanese country through the eyes of curators who are the guards of heritage.

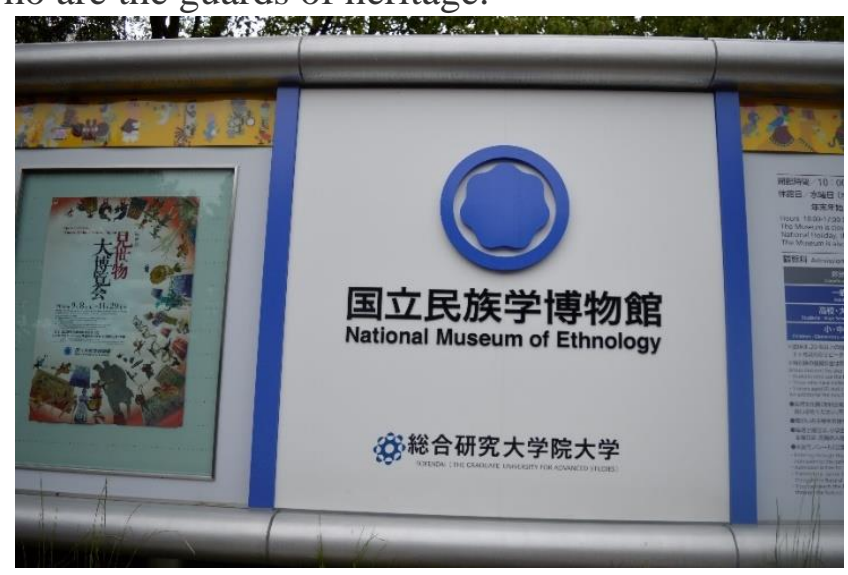

Minpaku museum, author 


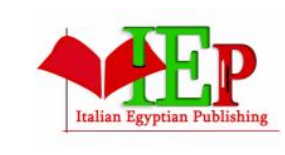

ISSN: 2735-5462

\section{INTERNATIONAL JOURNAL OF \\ ECO-CULTURAL TOURISM, HOSPITALITY PLANNING \\ AND DEVELOPMENT}

VOLUME 4, ISSUE 1, 2021, 49-71.

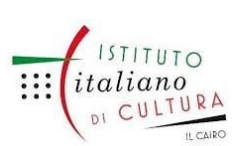

www.egyptfuture.org/ojs/

7- Recently Sharjah museum start to host curators and scholars from Arab region to improve their skills to exchange knowledge about the science of museum studies.

8- German archaeology institute offer 15days tour to the museum and heritage students and researchers to visit different type of the different German museums.

Al above mentioned examples are mainly used as soft power of different countries to support heritage preservation and keep peace between nations more over raise the value of the museums moral and give great trust for donors to share through funding or sponsorship.

9- American university Cairo

which is an independent, English, private research institution in Cairo and has so many programs with experts which handle Egyptology, Arabic language courses plus the main English language courses for local and international students, and one of the most famous professors work with it DR, Zahi Hawas and DR. Salima Ekram, who their names raise the value with any course they handle, (https://oyaop.com/opportunity/scholarships-and-fellowships/fully-funded-

scholarships-at-the-american-university-in-cairo/, n.d.).

10- Institut français d'archéologie orientale:

It is very supportive institute and make its unique library accessible for local researchers through the Egyptian ID to be members and gain more culture communities additionally to the French language courses and also held regular lectures for international professionals, it was established 1880 and it organizes several educational programs in different aspects one of them is called Imhotep program which pass to 12 participants, also it provide especial programs for French and another one for Egyptian and both target young researchers. (https://eg.ambafrance.org., n.d.)/ (https://www.campusfrance.org/imhotep, )

\section{1- DAAD:}

German Academic Association which was established 1925 around 2-6 million scholars in Germany and abroad have received DAAD funding, which budget derived from the federal funding for various ministries mainly the primary the German federal foreign office, European union and number of enterprises, organizations and foreign governments (https/:www.daad.de/en/the-daa, 2021)

\section{2- Hedayet institute program in Egypt:}

This program owned by private sector, which is for two to three weeks and enables students to travel in Egypt and learn about its culture while having their crash Arabic course. This is a program designed for groups of six or more students; The Hedayet Institute for Arabic Studies is one of the pioneer Arabic institutes devoted to the teaching of Arabic as a foreign language in Egypt. The programs varied from 100: 6500 US dollars according to the duration and program's needs. (https://www.hedayetinstitute.com/contact-us/, n.d.) 


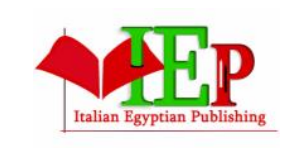

ISSN: 2735-5462
INTERNATIONAL JOURNAL OF

ECO-CULTURAL TOURISM, HOSPITALITY PLANNING

AND DEVELOPMENT

VOLUME 4, ISSUE 1, 2021, 49-71.

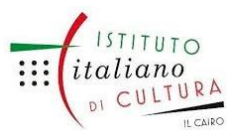

www.egyptfuture.org/ojs/

\section{3- $\quad$ Conference type (Annual conference of king Tut Ankh Amon)}

IN MAY2015, The first conference was established by the Grand Egyptian museum, the participant of the conference are consists of mangers, curators, students, researchers, conservators who are coming from all over the world such as Japan, England, Germany, Holand, Denmark, Italy.

\section{Values of the Educational tourism at the Egyptian museums}

Museums can be Use as a platform for debates and public hearings on urban design and the revival of city life, as well as to promote its relationship with local development stakeholders. Work with the museum to make its environment (parks, gardens) an element in any visit and to safeguard the surrounding cultural and natural landscapes.

Egyptian museum have great potential values to be center of Egyptology and ancient Egyptian history, art, culture and intangible heritage.

Coptic museum houses rare and unique collection around the world, which can promote courses of teaching Coptic language, Icon techniques, Christian art through reading the Icons and the Coptic symbols.

Additionally Islamic museum where is great collection from all Islamic world and very old museum since end of 19th which gives the museum chance to have very rich collection and can be a center for Islamic culture, heritage, art, history and Arabic language

According to interview with directors of some of the Egyptian museums who highlighted that there are so many researchers come from all over the world to have their fieldwork at the Egyptian sites and museums to study, inspect to get their practical fieldwork on new objects or check the original objects.

Integrate museums and their surroundings in urban planning and design programs with the business partners national and international.

Museum can be as the main source of services for educational tourist, urban business, the museum must understand his visitors needs and form several programs to courage them to come so museum must have all type of supplements of official papers, visa, accommodation, domestic transportation, teachers, and cars.

(ICOM, n.d.)

\section{Recommendation for museum's authority to improve the impact of the museum as an educational tourism tool}

Support museums locally, nationally and internationally by funding information and advertising support and by organizing the participation of museums in international fairs, events and use it as main house for international conferences.

- Support or organize packages that combine museum entrance, local transportation and access to other cultural activities. 


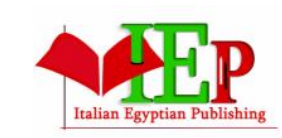

ISSN: 2735-5462

\section{INTERNATIONAL JOURNAL OF \\ ECO-CULTURAL TOURISM, HOSPITALITY PLANNING \\ AND DEVELOPMENT}

VOLUME 4, ISSUE 1, 2021, 49-71.

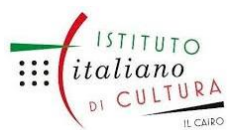

www.egyptfuture.org/ojs/

- Create incentives to organize passes for tourists as well as residents to facilitate their movement around the city where they stay or to travel to different cities.

- Create incentives opening hours and days for visits with local settings. - Promote coordination between tourist offices, hotels, restaurants and museums to offer an integrated supply of services for flights, accommodations, food and educational activities.

- Work on a fair sharing of revenue when museum tickets are sold to visitors by tourism offices to courage the quantity.

- make the museum Achieve \& data base accessible for researchers.

-museums offer accommodations for especial students groups and security instructions at the museum buffer zones for huge museums.

- Promote sustainable tourism principles, by, for example, making tourism accessible to all. -link the museum with business communities to improve the services and goods such as health insurance, oil companies etc...

\section{Conclusions \& recommendations:}

The museum can be the main source of services and suppliers for visitors, researchers, and students who are coming to stay or traveling for learning as an engine for economic development.

The museum should put a plan to complete the circle of services to gain, more socio-economic benefits from tourism education by several techniques.

Support the programs by services related to tourism industry such as the suppliers of Transportations, visa, flights, and guides.

Make agreements with ministry of High Education, solidarity \& social work, searches and science institutes and ministry of youth and sports.

Provide accommodation services at the museum if the museum has enough space such as the Grand Egyptian museum.

The museum must create its policy of using the objects, material and its partnership with other international museums.

All above mentioned services museum can form his unity to provide its Educational tourism partners so can deal with some locals for B\&B services or hostels and hotels or even by saving space at it to house his visitors as the new Egyptian museums have huge space such as National museum of Egyptian civilization (NEMC) and the Grand Egyptian museum which occupying 500.000 sq. with some building can be used as hostel for students.

Museums need team of professionals to raise their knowledge about Egyptian system, law of Egypt.

Need health insurance while they are staying in Egypt.

Peers learning to exchange knowledge and integrate Egyptian with international students and researchers.

Museums need domestic flights, drivers, food, computers, and internet deals to offer to researchers. 


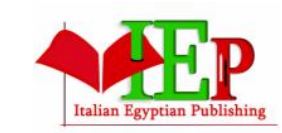

ISSN: $2735-5462$

\section{INTERNATIONAL JOURNAL OF \\ ECO-CULTURAL TOURISM, HOSPITALITY PLANNING \\ AND DEVELOPMENT}

VOLUME 4, ISSUE 1, 2021, 49-71.

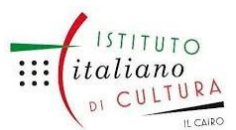

www.egyptfuture.org/ojs/

They pay to inspect the objects, taking photos, analyses materials, which means serval staff members deal who exchange the knowledge back and forward.

Finally, it is very clear it's a new type of tourism Egypt can offer through the museums and Archaeology sites as well as so many countries.

\section{Bibliography:}

http://www.aeraweb.org/field-school-program/2021.

https/:www.daad.de/en/the-daa. (2021, April).

https://culturalvistas.org/programs/internships-abroad/gip/internship-program-germany/ 2020.

https://eg.ambafrance.org.2021.

https://Idminstitute.com/academics/programs-and-degrees/study-abroad-programs/summerprograms/archaeology-field-school/. March 2020.

https://oyaop.com/opportunity/scholarships-and-fellowships/fully-funded-scholarships-at-theamerican-university-in-cairo/. (MAY 2019).

https://theculturetrip.com/europe/spain/articles/the-best-galleries-and-museums-in-b March 2021.

https://www.archaeologicalconservation.org. (June 2018 ).

https://www.britishmuseum.org/our-work/international/international-training-programme . (2021 , March ).

https://www.cabdirect.org/cabdirect/abstract/20103311195\#. (26/04/2021). london .

https://www.campusfrance.org/imhotep. (April 2019 ).

https://www.gooverseas.com/internships-abroad/italy/florence . (2021 , April ). Retrieved from https://www.gooverseas.com/internships-abroad/italy/florence .

https://www.jica.go.jp/english/ir/financial/index.html . (2020, May ).

https://www.smithsonianofi.com/internship-opportunities/ . (2021, March ). Retrieved from https://www.smithsonianofi.com/internship-opportunities/ .

ICOM. (n.d.). https://icom.museum/wp-content/uploads/2019/09/OECD-ICOM-GUIDEMUSEUMS.pdfhttps://icom.museum/wp-content/uploads/2019/09/OECD-ICOM-GUIDE-

www.oecd-ilibrary.org. (2021, APRIL). https://www.oecd-ilibrary.org/sites/74345b15en/index.htm/?itemld=/content/component. 


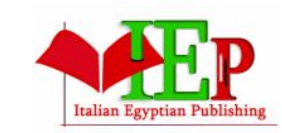

ISSN: $2735-5462$

\section{INTERNATIONAL JOURNAL OF \\ ECO-CULTURAL TOURISM, HOSPITALITY PLANNING AND DEVELOPMENT}

VOLUME 4, ISSUE 1, 2021, 49-71.

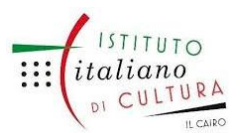

www.egyptfuture.org/ojs/

Retrieved from https://www.museumnext.com/events/digital-income-summit/.

affairs), g. D.

GLOBAL, I. (2021, April). https://www.igi-global.com/dictionary/virtual-tours-and-serious-game-forpromoting-educational-tourism-using-non-intrusive-human-computer-interfaces.

MUSEUMS.pdf.

\section{Sources}

The Ontario Ministry of Culture and Communications, Ontario Museum Notes: Practical Information on Operating a Community Museum, Number 10 Developing a Staff Training Policy. (n.d.).

UNESCO. (2021, April). https://en.unesco.org/themes/museums.

(2019). world tourism barometer. UNWTO, United nation world tourism orgnization.

Received: April 2021

Accepted: June 2021 